\title{
THE GOORENG GOORENG CULTURAL HERITAGE PROJECT: PRELIMINARY RESULTS OF ARCHAEOLOGICAL RESEARCH, 1993-1997
}

\author{
IAN LILLEY AND SEAN ULM \\ Aboriginal and Torres Strait Islander Studies Unit, University of Queensland, \\ Brisbane, Queensland, 4072, Australia
}

\begin{abstract}
This paper summarizes the background to, and preliminary results of, archaeological investigations conducted between 1993 and 1997 under the auspices of the Gooreng Gooreng Cultural Heritage Project. The implications of these results are briefly considered before research in progress and future research directions are outlined.
\end{abstract}

\section{Introduction}

The collection of papers in this volume draws principally on a selection of Honours theses to outline the preliminary results of archaeological surveys and excavations undertaken between 1993 and 1997 as part of the wide-ranging Gooreng Gooreng Cultural Heritage Project (GGCHP), an interdisciplinary Aboriginal cultural heritage study of the BurnettCurtis region in southern Central Queensland. The project was initiated by the Aboriginal and Torres Strait Islander Studies Unit at the University of Queensland in collaboration with Aboriginal people from the study area (see Clarkson et al. in prep.; Jolly 1994; Lilley et al. 1998; Lilley and Ulm 1995; Lilley et al. 1996; Lilley et al. 1997).

The archaeological component of the GGCHP aims to:

- identify and document Aboriginal archaeological sites in the study area;

- develop an archaeological sequence encompassing coastal and inland parts of the Burnett-Curtis region; and,

- compare that sequence and its explanation with sequences from the Central Queensland Highlands, southeast Queensland and regions further afield to determine how the Burnett-Curtis sites fit into the broader archaeological patterns which have been discerned over the last four decades of research in Queensland.

The investigations build on work by Queensland government archaeologists (e.g. Burke 1993; Godwin 1990; Rowland 1987) and private consultants (e.g. Alfredson 1989, 1993; Hiscock 1982; Lilley 1995a), and are linked with other components of the GGCHP, including studies of language revitalization (Jolly 1994), contemporary social landscapes (Clarkson et al. in prep.) and the repatriation of Aboriginal cultural property (Ulm and Lilley 1996). The aims of the archaeological enquiry have been advanced through a combination of archaeological scholarship and the direct involvement of local Aboriginal people with knowledge of archaeological sites and other places of significance to their communities. The work contributes basic knowledge of Aboriginal sites in a region about which little is known from an archaeological perspective and in which housing and other development is proceeding at an accelerating pace. The surveys and excavations revealed evidence for extensive Aboriginal occupation dating from the late Pleistocene through to the historical period. These findings provide a basic framework for understanding past Aboriginal lifeways in the wider Burnett-Curtis and for managing the region's Aboriginal cultural heritage places.

\section{Aboriginal Involvement and Consultation}

The research described here was undertaken in close co-operation with the Gurang Land Council Aboriginal Corporation, the Representative Body for the region under the provisions of the Native Title Act 1993, as well as with other members of the Gooreng Gooreng Aboriginal community. Field crews from the University of Queensland Aboriginal and Torres Strait Islander Studies Unit and Gooreng Gooreng Aboriginal traditional owners undertook 108 days of fieldwork between 1993 and mid-1997. Effective mechanisms for Aboriginal consultation on the project were established and have been maintained primarily by Michael Williams, one of the principal investigators managing the GGCHP. A senior Gooreng Gooreng man from the study area, Williams is also Director of the University of Queensland Aboriginal and Torres Strait Islander Studies Unit. His contribution to the management of the project has ensured that Aboriginal aspirations, worldviews and intellectual traditions have been included as a vital component of all stages of the research program.

\section{The Study Region}

The study area encompasses the region between Bundaberg and Gladstone on the coast and Monto near the main drainage divide in the west (Figure 1). This region lies between two of the archaeologically best-known parts of the country, the Central Queensland Highlands to the west and southeast Queensland to the south. It is roughly congruent with the area Williams (1981) identified as the country of 
Gooreng Gooreng speakers at the time of European contact (Figure 1; also Clarkson et al. in prep.). Elsewhere, this language community has also been referred to variously as Gureng Gureng, Gurang Gurang, Goeng, Koreng and Koreng Goreng (see Jolly 1994; Tindale 1974:168, 177).

The study area occupies an unusual biogeographic and geomorphic position, which may have important ramifications for the investigation of its archaeological record. First, it is situated only $50 \mathrm{~km}$ south of the Tropic of Capricorn and thus lies in the area where the region commonly regarded as southeast Queensland meets Central Queensland. Southeast Queensland forms a broad ecotone between the coastal environments of the tropical north and the temperate south (Stanton and Morgan 1977). The location of the study area on the northern edge of this ecotone may have periodically and perhaps continually impinged upon past patterns of human behaviour in the region. For instance, it may have encouraged a more tropical focus in subsistencesettlement systems, or more northerly- rather than southerly-oriented patterns of inter-group interaction.

Second, the study area lies at the northern extremity of that part of Australia's east coast not protected by the Great Barrier Reef. However, while the coastline of the study area is in that respect unlike the coast to the north, and exhibits various characteristics in common with more southerly coasts, it differs radically from the latter in its geographical orientation or alignment and thus also in important aspects of its hydrology and geomorphology. To focus on southeast Queensland in particular, most of the mainland coast north of the Tweed River is protected from full oceanic conditions by the massive transgressive dunes of Fraser, Moreton, and North and South Stradbroke Islands. The coast in the study area, on the other hand, is open to full oceanic conditions, but in the main is characterized by beach ridges rather than massive dunes. High dunes do occur in the area of investigation, just as beach ridges occur to the south. However, the relative proportions of the areas covered by these two landform types in the study area are generally the opposite of those in southeast Queensland. This means the high dunes distinctive of large sand islands such as Fraser and Moreton are largely replaced by prograding shorelines composed of low beach ridge systems which have formed since sea-level stabilisation following the last marine transgression. This difference results from the northwesterly shift in coastal orientation north of Fraser Island, as can be determined from the characteristics of the Cooloola coast. Cooloola extends south from Fraser Island as far as the Noosa River and is the only significant stretch of mainland coast in southeast Queensland, other than the study area, which is open to the ocean. Like the large sand islands, though, the Cooloola coast is aligned northnortheast, and thus like the large sand islands, it has high dunes oriented north-northeast.

The foregoing means that while the coast in the study area is in some important respects more similar to coasts further south along Australia's eastern seaboard than to those further north, the resources available to past Aboriginal populations in the study area may have differed in gross as well as more specific terms from those accessible to the south, both on the ocean beaches of Cooloola and the major sand islands as well as on the protected mainland coast and western coasts of the sand islands. Such variations in resource distribution mean the locations and contents of coastal archaeological sites in the study area could differ quite radically from those on more southerly parts of the Australian east coast, exposed to the open ocean or not. It would also mean that while it is open to eceanic conditions, past-and-present-eresional and depositional characteristics of the coast would differ to varying degrees from those of the ocean beaches as well as protected beaches to the south. This suggests patterns of site visibility and survival could differ more substantially from those to the south than might be expected otherwise.

Cania Gorge, the focus of the project's inland investigations, is an extensive system of low, dissected sandstone plateaux. Exhibiting some spectacular escarpments, the gorge covers an area of approximately $5,000 \mathrm{ha}$ in the upper Burnett River basin, about $120 \mathrm{~km}$ from the coast (Figure 1). It is situated on the extreme western margin of country claimed traditionally as Gooreng Gooreng, where it borders Gangulu and Wuli-Wuli countries to the west (Horton 1994). A large dam has been built at the north end of the main area of escarpments, but most of the gorge proper lies in what remains of the Cania pastoral station, those parts of the station which have become Cania Gorge National Park, or in surrounding State Forest. Historically, the gorge area has been used primarily for grazing, but it was the focus of intensive alluvial gold mining activity in the late 1800s. The township of Cania, which reached the zenith of its development during the gold rush, now lies under the dam.

In view of the foregoing discussion, it is interesting to note that linguistic and ethnographic evidence (see Clarkson et al. in prep.; Jolly 1994; Williams 1981) indicates that while Aboriginal people in the study area undoubtedly had links to the north, most of their cultural ties at the time of European contact were to the south. The Gooreng Gooreng language, for instance, is closely related to Gubbi Gubbi and Waka Waka rather than to 


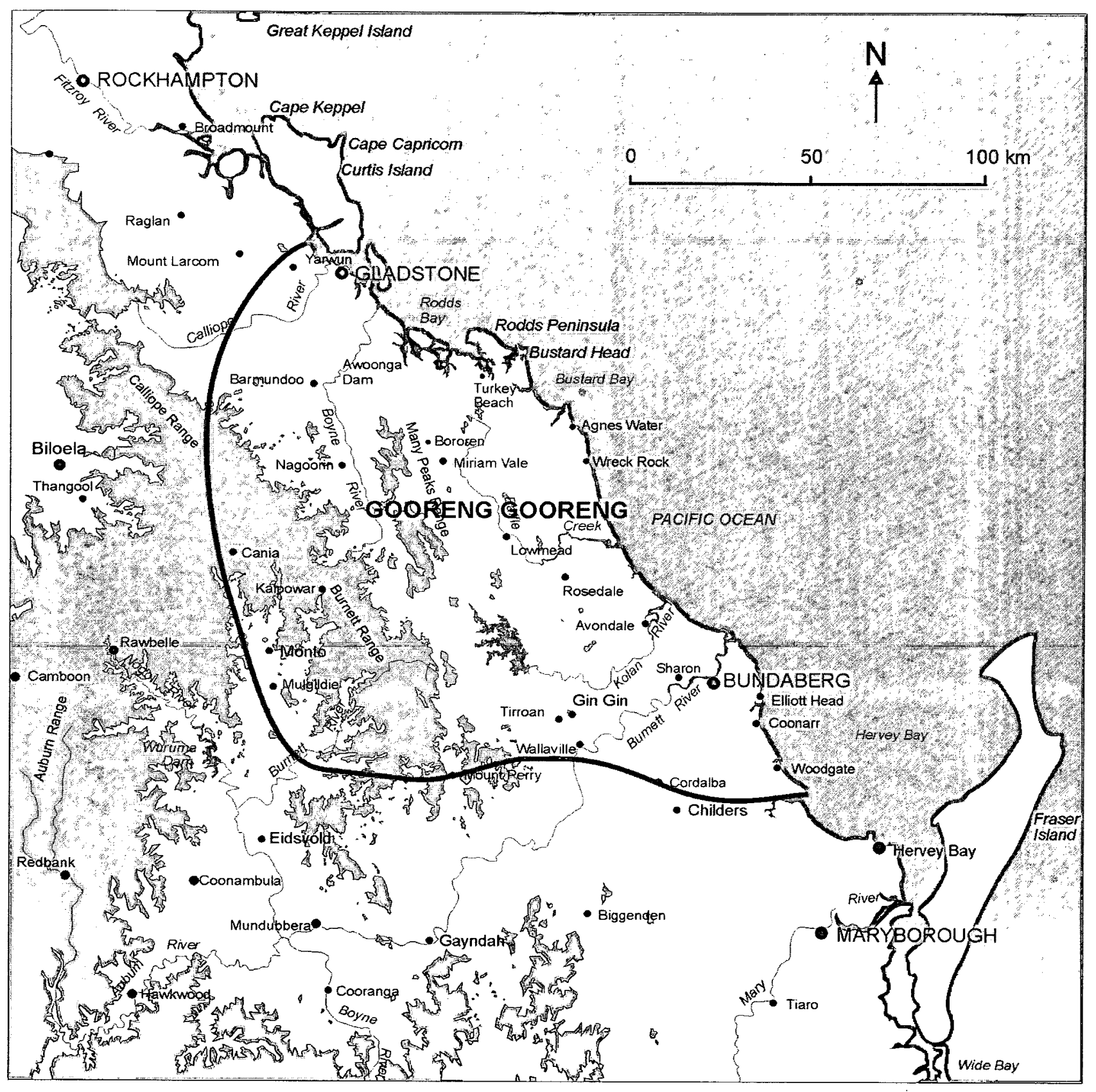

Figure 1. The study area, showing places mentioned in the text and the general distribution of Gooreng Gooreng speakers (after Horton 1995; Williams 1981). 
languages in the Rockhampton area. Ethnohistoric accounts document a clear schism between Gooreng Gooreng and Bayali peoples and their Darambul neighbours to the north, which manifested itself in warfare and separate alliance networks.

\section{Previous Research}

Prior to the 1990s, knowledge of the archaeological record and cultural heritage resources of the study region was extremely limited. This is particularly evident in comparison to the extensive investigations conducted in the Central Queensland Highlands to the west (e.g. Beaton 1977; Johnson 1979; Morwood 1979, 1981, 1984; Mulvaney and Joyce 1965; Richardson 1992; Stern 1980; Walsh 1984), the Keppel Islands and adjacent mainland coast to the north (e.g. Rowland 1981, 1985, 1992) and the Great Sandy Region and Moreton Bay to the south (e.g. Frankland 1990; Hall and Hiscock 1988; Lauer 1977, 1979; McNiven 1990, 1998; Ulm and Hall 1996).

Despite its paucity, archaeological research in the Burnett-Curtis region in fact extends back to the 1890s, when interest arose in the Burnett River Engravings site. This site was included in early discussions of Aboriginal rock art by Mathews (1897, 1910) and Elkin (1949), as well as in more recent works by Quinnell (1976) and Maynard (1976, 1979). Sutcliffe $(1972,1974)$, who supervised a salvage operation at the site in the early 1970 s, wrote a draft Master of Arts thesis on the salvage process, but apparently never submitted the manuscript for examination. Rola-Wojciechowski (1983) undertook a quantitative analysis of a sample of the engravings assemblage as part of her Honours thesis at the University of New England. She suggested that the predominantly non-figurative art assemblage represented at the site displayed affinities with other sites in southeast Queensland but was distinct from assemblages recorded for the Central Queensland Highlands.

In the latter part of the nineteenth-century and throughout the twentieth-century, various Aboriginal artefacts from the general region have also been donated to or otherwise acquired by private collectors, the Queensland Museum and the Anthropology Museum at the University of Queensland. Unfortunately, many of these artefacts are not well documented and it is difficult to determine whether they truly originated in the study area.

In 1915, Hamlyn-Harris conducted a surface collection of 330 stone artefacts and samples of shell from a "feeding-ground" at Bargara, east of Bundaberg, after the site was brought to his attention by Lionel C. Ball of the Queensland Geological Survey. Ball had donated a small collection of 24 stone artefacts from the site to the Queensland Museum earlier that year. Ball (1915) noted that the "chips are scattered in some profusion along the summits of the sand ridges" which "rise immediately behind the beach". This pattern of site location on beach ridges in the study area has been confirmed by recent research (see Lilley 1994a; Lilley and Ulm 1995).

Hamlyn-Harris (1915:104) noted "secondary chipping" or retouch on some artefacts in the collection. The surface collection consisted of "shells, together with one blank (unfinished) axe of silicified sandstone, two primitive stone tools also made of the same material, a large quantity of flakes, chips, scrapers, drills and gouges made of silicified sandstone, jasperoid, petrified wood, quartz, etc., and a basalt hammer" (Hamlyn-Harris 1915:104). Hamlyn-Harris (1915:104) concluded that many of the raw materials represented in the collection derived from non-local sources and "had evidently been brought some distance by them for this purpose."

In 1979, this stone artefact collection was analysed by students from the University of Queensland (Findlay 1979; Horsfall 1979; Horsfall and Findlay 1979). The presence of numerous stone artefacts, including retouched flakes, and abundant shellfish remains described for the site led Horsfall and Findlay (1979:6) to suggest a pattern of "intensive and/or prolonged use of the site."

From the 1970s, several archaeological sites in the area were recorded by State Government staff, including the Crevasses Art Site (JE:A25) at Cania Gorge, which was recorded in 1982, and a quarry site and axe grinding grooves on the coast just south of Agnes Water, recorded in 1978. It was not until the mid-to-late $1980 \mathrm{~s}$, however, that the number of reported Aboriginal archaeological sites in the study region increased markedly with the growing numbers of surveys carried out by independent archaeological consultants as part of cultural heritage environmental impact studies (see Alfredson 1987, 1989, 1990, 1991, 1992, 1993; Barker 1993; Davies 1994; Duncum 1991; Gorecki 1995; Hall 1980, 1981, 1985; Hatte 1992; Hill 1978; Lilley 1980, 1994a, 1994b, 1995a, 1995b, 1995c, 1995d, 1995e; Neal 1986; Spencer 1995). With the exception of a few broad overviews (e.g. Gorecki 1995), the majority of these consultancy reports have focussed on geographicallylimited development impact areas and adopted site discovery-oriented research designs rather than predictive site location models. Further, most of these studies have been undertaken in coastal or nearcoastal areas, creating a sampling bias against site representation in sub-coastal and inland parts of the region. 


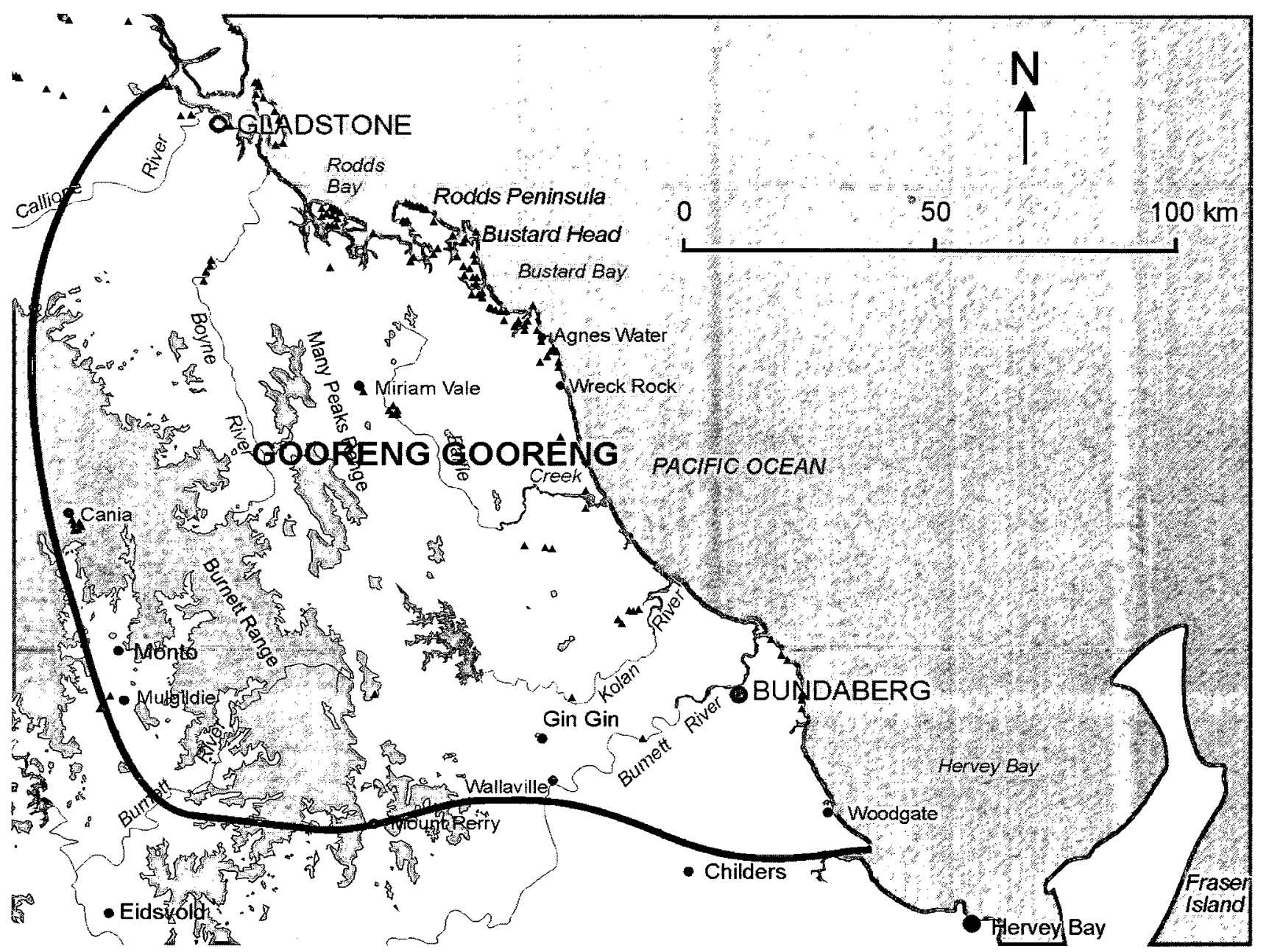

Figure 2. The study area, showing all recorded archaeological sites as triangles (after Burke 1993; Davies 1994; Gorecki 1995; Lilley 1994; Lilley et al. 1997; Neal 1986; Rowland 1987; Ulm and Lilley this volume). 
Many of the foregoing surveys report finding little or no archaeological material (e.g. Alfredson 1989, 1990, 1991, 1992; Hall 1980, 1981; Hill 1978; Lilley 1994b, 1995a, 1995b, 1995c, 1995d, 1995e; Spencer 1995), although some sites were surface collected and several subjected to limited analysis (see Alfredson 1987). This apparent scarcity of archaeological material in the study region led Alfredson (1990:10) to comment that:

The present survey results are in keeping with the results of the other archaeological surveys conducted in the region. The relatively sparse archaeological record does not indicate a large Aboriginal population inhabiting this part of the coast. It seems that the well-watered country behind the coastal ranges rather the [sic] coast may have been the main focus for the regional Aboriginal population.

On the basis of the small number of artefacts observed east of Monto, Spencer (1995:21) suggested that "in spite of a richly đ̛̣verse rēsoüurce base ... few people lived and foraged here", and concluded that "more studies in this region will shed further light on this matter, but until then we must assume that the lithic resources had little importance to the Aboriginal occupants of the area" (Spencer 1995:22).

During an impact assessment survey for Awoonga Dam, southwest of Gladstone, Hall (reported by Lilley 1980) identified four sites on the banks of the Boyne River. Only one exhibited significant integrity, the others having been severely disturbed by European activities. Hiscock (1982) conducted the first detailed archaeological investigations and excavations in the study region while following up Hall's (Lilley 1980) original study. Hiscock excavated a total of $1 \mathrm{~m}^{2}$ in addition to recording surface artefact scatters and the attributes of samples of the artefacts they contained. The undisturbed site covered approximately $8,700 \mathrm{~m}^{2}$ and exhibited artefact densities up to $29 / \mathrm{m}^{2}$. The assemblage was dominated by flakes but also included cores, retouched flakes and flaked pieces, with artefacts restricted to the top $6 \mathrm{~cm}$ of the deposit. No organic material suitable for radiocarbon dating was recovered. Hiscock (1982:20) argued that the site is less than 1,000 years old on the grounds that the deposit was shallow, the river bank itself is probably very recent and the artefacts did not include backed blades or points suggestive of an earlier age. He (1982:19) concluded that the "archaeological evidence does therefore suggest that Aboriginal activities were concentrated close to the Boyne River".

Several studies conducted over the last decade have also revealed abundant Aboriginal cultural materials in the region, particularly on the coast (Figure 2). In 1987, Rowland (1987) conducted a "broad cursory investigation" of the coast from Bundaberg to Turkey Beach. Prior to his survey, only nine sites were recorded on the Queensland State Site Register for the Bundaberg 1:250,000 map sheet. Rowland located a further seven sites, although only one, KE:A11 just to the south of the Town of Seventeen Seventy, was reported to be of any significant size. Rowland noted that "substantial middens are rare", sites are located "either atop rocky headlands or in sheltered estuaries", and that "smaller scatters of shells are located along open beaches". He (1987:17) concluded that:

Whether this is a true reflection of Aboriginal settlement patterns in the area or an expression of geomorphological factors affecting preservation and visibility is a problem still to be resolved. Certainly the extent of erosion along the open coastal dune systems of the area would suggest that the loss of sites may be an important factor affecting the above pattern.

Two other localised surveys have been conducted in the area, one on Facing Island (Ringland 1978), where seven extensive shell midden sites were located, and one taking in part of Eurimbula National Park, where an extensive stratified midden deposit on the western bank of Round Hill Creek was identified (Godwin 1990).

In 1993, Burke (1993) conducted selective systematic archaeological surveys of the coast between Raglan Creek in the north and Agnes Water in the south and up to $1 \mathrm{~km}$ inland from the mainland coastline as part of the Curtis Coast Scan project (see QDEH 1994). Although it extended south to overlap with Rowland's survey at Round Hill Creek, Burke's study was primarily concerned with the area to the north of Rodds Peninsula. In addition to re-recording 24 previously-registered sites, Burke (1993:26) documented 179 unrecorded sites, including shell middens $(72.4 \%)$, stone artefact scatters $(23.3 \%)$, quarries $(2 \%)$ and scarred trees $(1.5 \%)$.

\section{The Present Study - Methods and Results}

The archaeological component of the Gooreng Gooreng Cultural Heritage Project has been structured as a multi-stage investigation. Owing to the lack of basic knowledge of the archaeological record of the study region, Stage I (reported here) involved detailed literature reviews and general reconnaissance of the study area coupled with exploratory site surveys and test excavations designed to provide a basic framework for future research.

Twelve sites were investigated by subsurface excavation as part of the Gooreng Gooreng Cultural Heritage Project during the period covered by this report. Two of these are open stratified midden deposits on the coast: Eurimbula Site 1 and the Mort 
Creek Site Complex (see Ulm and Lilley this volume). Ten rockshelters in Cania Gorge have also been test excavated: Big Foot Art Site, Boulder 1, Bushranger's Cave, Contact Cave, Fern Tree Pool Shelter, Grinding Groove Cave, Long Gallery, Picnic Art Site, Road Cave 1 and Roof Fall Cave (see Westcott, Lilley and Ulm this volume). These excavations revealed an occupational sequence spanning the period from the Last Glacial Maximum 18,000 years ago to the time of European contact.

\section{Excavation Methods}

Excavation procedures generally followed those outlined by Johnson (1979). Single or adjoining $50 \mathrm{~cm}$ $x 50 \mathrm{~cm}$ pits were hand-excavated by trowel in arbitrary $2-5 \mathrm{~cm}$ (c.10kg) excavation units (XUs) within natural stratigraphic units. All excavated sediment was weighed in buckets on a tared spring balance and elevations were recorded at the beginning and end of each XU, using either an autoset level and stadia rod or a local datum and a string-line and level. All sediment was dry-sieved on site through $6 \mathrm{~mm}$ and $3 \mathrm{~mm}$ nested screens, although some excavation units required a combination of dry and, later, wet-sieving if the moisture content of the matrix prevented effective dry-sieving. All sieve residue was retained, with the exception of large roots, which were weighed and discarded in the field. Sediment samples (c.200g) were taken from each excavation unit from the material which passed through the $3 \mathrm{~mm}$ sieve. Coarse and fine sieve fractions from each $X U$ were bagged separately in the field. Each excavation crew kept a daily general $\log$ as well as detailed notes of each XU, completed section drawings of at least two sides of every pit and made comprehensive colour photographic records of all work.

\section{Survey and Test Excavation Results}

On the coast, systematic site surveys were conducted in all major environmental zones including open beaches and rocky headlands, marine estuary systems, swamp and wetland margins, and the coastal ranges. A total of 79 Aboriginal cultural heritage places have now been identified on the southern Curtis Coast (Ulm and Lilley this volume:Appendix A). Surveys have revealed a consistent pattern of site location. Extensive midden deposits with evidence for multiple occupations and diverse activities are limited exclusively to the margins of tidal estuaries in close proximity to their mouths (see Ulm and Lilley this volume:Figures 1, 8-9). Such sites have been found on the northern and southern banks of Round Hill, Middle and Pancake Creeks. All are exposed in erosion faces extending over several kilometres. Relatively small, discrete, low density surface scatters of marine shell and stone artefacts made on local materials were noted on exposed headlands, while midden deposits on the open beaches themselves were generally very limited in extent and composition and often located in deflated contexts. Beach ridges and transgressive dunes located just inland of the modern coastline contain abundant evidence for extensive but shallow site complexes (Lilley 1994a; Lilley and Ulm 1995).

The two sites which were test excavated during Stage I of the project are the largest complexes of shell midden deposits found in the area. As noted above, these are Eurimbula Site 1 on the western bank of Round Hill Creek (Lilley et al. 1996; Reid 1997) and the Mort Creek Site Complex on the western bank of Mort Creek at the northern end of Rodds Peninsula (Carter 1997; Lilley et al. 1996). Radiocarbon dates from the 1995 excavations indicate Eurimbula Site 1 was occupied by about 3,000 years ago, while the Mort Creek Site Complex was occupied from about 2,500 years ago (Lilley et al. 1996). These results confirm Aboriginal occupation of the coast in this region from at least $3,000 \mathrm{BP}$ and conform with other dates obtained for the Queensland coast (Ulm et al. 1995; Ulm and Hall 1996; cf. Nicholson and Cane 1994). In particular, the dates are similar to the earliest dates obtained at the site of Booral in the Great Sandy Straits not far to the south of the study area (see Frankland 1990) as well as those from the Keppel Islands just to the north (Rowland 1992). Results from these sites and other aspects of the project's coastal focus are discussed at greater length elsewhere in the volume (Carter et al. this volume; Ulm et al. this volume; Ulm and Lilley this volume).

Stage I surveys in Cania Gorge resulted in the documentation of 23 Aboriginal cultural heritage places, 21 of which had not been previously recorded (Lilley et al. 1997; see Westcott, Lilley and Ulm this volume:Figure 1). Six of the sites exhibit rock art including hand prints, tracks and animal motifs. While numerous rockshelters containing archaeological deposits were located at the base of the escarpments forming the gorge, very little material was observed in open contexts and what was found appeared to be in reworked deposits. It is hypothesized that in addition to alluvial gold mining late last century, periodic flooding of Three Moon Creek and its tributaries may have had a negative impact on the preservation of any open sites once present on the alluvial flats and terraces bordering creek margins.

Ten rockshelters within a $15 \mathrm{~km}^{2}$ area at the southern end of the gorge were test excavated during Stage I of the project (Lilley et al. 1997; Lilley et al. 1998). No archaeological material was observed during excavations at two of the sites (Fern Tree Pool 
Shelter and Long Gallery), and only sparse material, principally flaked stone, was found in three other sites (Bushranger's Cave, Picnic Art Site and Boulder 1). The five remaining sites, Contact Cave, Grinding Groove Cave, Roof Fall Cave, Big Foot Art Site and Road Cave 1, on the other hand, yielded abundant cultural remains to the base of excavations.

Excavations at Roof Fall Cave returned a basal date of 18,576 years on a sample of charcoal from a depth of $69-74 \mathrm{~cm}$ (Lilley et al. 1998). Although at the time of writing the association of this date with evidence for human occupation of the rockshelter had yet to be confirmed by further excavation, there is no doubt that the rockshelter was being used by Aboriginal people by at least 8,000 years ago, which is about the time that Big Foot Art Site, just $80 \mathrm{~m}$ away, was first occupied.

Westcott (1997) conducted the first detailed analysis of stone artefacts in the Cania Gorge region in her investigation of Square I5 at Big Foot Art Site (KE:A07), one of the sites recorded in the gorge before the present study began. She demonstrated significant increases in the rate of stone artefact discard at the site between about 4,400 and 3,200 years ago which she could not link with technological change. This finding suggested that there may have been a period of more intensive activity at the site at this time, or changes in site function. Her results are discussed in more detail elsewhere in this volume, as are other aspects of the project's work in the Cania area (Westcott, Lilley and Ulm this volume; Eales et $a l$. this volume; Westcott, Lilley et al. this volume).

\section{Discussion}

The discovery of Pleistocene evidence at Cania Gorge represents an excellent opportunity to examine the validity of the Central Queensland Highlands and southeast Queensland sequences and influential models of cultural change which have been built on them. The range of sites investigated, with initial occupation dating from the Last Glacial Maximum, the early Holocene and the late Holocene, provides the chance to explore the nature of past Aboriginal use of this region, and how this may have changed through time, thus furthering considerably the original aims of the Gooreng Gooreng Cultural Heritage Project (see Lilley and Ulm 1995). Ultimately, however, this new evidence allows us to relate our findings to wider questions concerning the rates, patterns and causes of change in the Australian archaeological record.

Of particular interest in this latter regard is the nature of human activity during the Last Glacial Maximum. During this environmentally-harsh period, the gorge system would have been close to the eastern edge of a much-expanded arid zone. It has been suggested that during this time, regional populations may have concentrated in relatively well-watered refuges in "piedmont/montane uplands and riverine/gorge systems" like Cania Gorge (Veth 1989:84; also Hiscock 1988; Morwood and Hobbs 1995; Smith 1989). While this model is attractive in many ways, it remains to be determined whether such a pattern observed in different regions can be legitimately related to the same phenomenon (Holdaway 1995:794).

Cania Gorge also provides a testing ground for models of change in the post-glacial period, particularly those associated with alterations in production and productivity in the mid-to-late Holocene (Lourandos 1997). Beaton (1977) and Morwood (1984) have identified such changes for the Central Queensland Highlands region, and it may be that the existence of sites in Cania Gorge established during the late Holocene reflects a similar pattern. On the other hand, given the antiquity of occupation at Roof Fall Cave and Big Foot Aitt Site, we should be able to test whether the archaeological record at Cania Gorge indicates processes operating over longer time scales, such as the late Pleistocene-early Holocene processes identified in southeast Cape York Peninsula, for example, by Morwood and Hobbs (1995) and David and Chant (1995).

As noted, the results of excavations on the coast confirm Aboriginal occupation of the coast in this region before 3,000 $\mathrm{BP}$ and conform with other dates obtained for the Queensland coast (Ulm et al. 1995; cf. Nicholson and Cane 1994). Further studies at these sites and at others in their vicinity will aim in part to explicate local sequences of chenier, sandy beach ridge and midden formation and to determine whether the antiquity of coastal occupation in the study area extends back to the time of sea-level stabilisation 6,000-7,000 years ago.

\section{Continuing and Future Research}

Sorting and analysis of the test excavated material is now underway and will continue for some years. Various undergraduate research projects and Honours projects have already been completed, all focussing on basic questions about the excavated finds (see Carter 1997; Chicoteau 1998a, 1998b; Culbert 1996; Eales 1998a; L'Estrange 1998; Reid 1997, 1998; Suarez 1998; Westcott 1997). A PhD scholar recently commenced research on late Holocene coastal mobility strategies in the Agnes Water-Seventeen Seventy area (Ulm in prep.). Another has recently begun augmenting the survey and excavation project in Cania Gorge (Eales in prep). These studies and continuing analysis and discussion of the data generated by this project will ensure that the full potential of this project is realised. Future studies will 
focus particular attention on the descriptive analysis of animal and plant remains and stone artefact technology and typology in an attempt to understand changing patterns of resource utilization and artefact manufacture. Taphonomic considerations will receive high priority in the faunal analysis, on the coast to augment the study of foraminifera in the determination of the origins of marine shell deposits (Lilley and Brian 1995; Lilley et al. 1999), and in the hinterland to distinguish humanly-deposited bone from the results of carnivore activity and other sources of bone.

Another important issue for the future is postdepositional disturbance. Australian archaeologists have often been quite unsophisticated in their strategies for dealing with post-depositional disturbance of human occupation residues from sandstone rockshelter deposits. Hughes and Lampert (1977) and Johnson (1979) made earlier contributions to such questions, but it was not until Stern (1980) employed conjoin analysis to examine some Central Highlands material that Australian archaeology first saw in use a reliable method for gauging vertical displacement of stone artefacts in archaeological deposits (see also Hiscock 1988). Apart from the work of Stern (1980) and more recently Richardson (1992), conjoin analysis has not been much used in Australia, perhaps because it is extremely timeconsuming. Despite this last constraint, samples of excavated stone artefact assemblages from the sandstone rockshelters and caves investigated during the present study will be subjected to conjoin analysis in an effort to cast further light on the well-known difficulties with post-depositional movement of cultural material in such sites (conjoining identifies and rejoins pieces of stone broken apart during artefact manufacture and can indicate how far through a deposit originally adjoining fragments have been moved apart by disturbance since deposition).

Study of stone artefact assemblages will seek to characterize and explain technological and typological variation since the time of first colonization of the study area, initially through the analysis of the reduction sequences and formal artefact types represented in the assemblages (e.g. Holdaway 1995). This will facilitate the identification of variation not encompassed by current two- or three-part models of change in Australian stone tool manufacture which are founded largely on the Central Highlands sequence. Finally, the limited amount of rock art known to be present at Cania Gorge is being recorded in detail and systematically assessed in relation to its similarities with art elsewhere in eastern Australia (Chapman 1999). Continuing attempts are being made to date the art through excavation of painted surfaces and/or utilized ochre.

\section{Postscript: Reports and Publications Arising from} the Project

Staff and students associated with the project have presented the results of their investigations in a variety of formats. Nine plain English Aboriginal community reports on the results of fieldwork stages were produced during the period covered by this volume. They were disseminated widely in the Gooreng Gooreng Aboriginal community and relevant government instrumentalities including the Department of Environment, Department of Forestry and the Miriam Vale Shire Council. Four scientific papers have been published in refereed journals (see Lilley et al. 1998; Lilley and Ulm 1995; Lilley et al. 1999; Lilley et al. 1996). In addition, work-inprogress papers have been presented at national Australian Archaeological Association annual conferences (Eales 1998b; Lilley 1994c), at the Taphonomy Symposium hosted by the Australian National University (Lilley and Brian 1995), in the Australian Institute of Aboriginal and Torres Strait Islander Studies seminar series (Lilley and Williams 1997) and at in-house seminars at the University of Queensland which have been attended by both academics and members of the Gooreng Gooreng Aboriginal community (Lilley 1995f; Lilley et al. 1997a; Lilley et al. 1997b; Ulm 1997; Ulm et al. 1997). Short summaries of various aspects of the project have also appeared in newsletters (Lilley 1997; Ulm and Lilley 1996) and newspapers (McAllister 1995, Schultz 1997). The project will also result in nominations to the Register of the National Estate, Queensland Department of Environment site record cards and draft entries in the Queensland Heritage Register.

Copies of all materials produced by the project are progressively lodged with the Gurang Land Council Aboriginal Corporation and (with community permission) the Australian Heritage Commission Library, the Australian Institute of Aboriginal and Torres Strait Islander Library, the Queensland Museum and the Fryer Library at the University of Queensland.

\section{Acknowledgments}

The Gooreng Gooreng Cultural Heritage Project has been carried out under Sections 27 and 28 of the Cultural Record (Landscapes Queensland and Queensland Estate) Act 1987 under permits CC/27/RES/008-93, CC/27/RES/011-94, CC/27/RES/001-95, CC/04/RES/96 and $\mathrm{CC} / 01 / \mathrm{RES} / 96$. Surface collection and excavation of scientific (archaeological) materials in National Parks was conducted under Regulation 12 of the National Parks and Wildlife Act 1975-1984 under permits 1789 and 1997 and under the Nature Conservation Act 
1992 Nature Conservation Regulation 1994 under permits H1/000016/95/SAA, C6/000028/95/SAA and C6/000028/97/SAA. Permits to traverse State Forest in the Monto Forestry District was undertaken under permits 719, 753, 795 and 831 under The Forestry Act 1959.

The project has been generously funded by the National Estate Grants Program of the Australian Heritage Commission, the Australian Institute of Aboriginal and Torres Strait Islander Studies, the Australian Research Council and the Australian Institute of Nuclear Sciences and Engineering. We thank the Gurang Land Council Aboriginal Corporation and the Queensland Environmental Protection Agency for their continuing assistance and participation in this project.

Dr Luke Godwin, formerly of the Queensland Department of Environment (Central Coast Region), provided assistance and advice throughout the early stages of the project. Valuable advice and assistance were also provided by Scott L'Ostè-Brown of the Queensland Department of Environment (Central Coast Region) and Denis Dray, Neil Teague and Brett Johns (Queensland National Parks and Wildlife Service).

For their collaboration in fieldwork we are grateful to members of the Gooreng Gooreng Aboriginal community: Colin Johnson, Mervyn Johnson, Michael Williams, Ron Johnson (Sr), Ron Johnson (Jr), Hilton (Charlie) Johnson, Vicki Johnson, Cedric Williams and James Williams.

Students from various institutions and others have provided invaluable assistance in the field: Brit Asmussen, Libby Biggs, Greg Bowen, Nicola Bristed, Deborah Brian, Melissa Carter, Chris Chicoteau, Chris Clarkson, Shane Coghill, Malcolm Connolly, Sebastian Crangle, Nick Culbert, Garrick Hitchcock, Lynette Hughes, Fiona Hutton, Debbie Kilroy, Joe Kilroy, Vanessa Krueger, Sarah L'Estrange, Sean McBride, Paul McInnes, Carney Matheson, Catriona Murray, Kate Quirk, David Reid, Jill Reid, John Richter, Gail Robertson, Sarah Sheridan, Stephen Skelton, Linda Tebble, Sophie Thompson, Deb Vale, Catherine Westcott and Nathan Woolford.

In the laboratory we thank Deborah Brian for guiding initial analyses and our tireless laboratory volunteers and postgraduate students: Brit Asmussen, Melissa Carter, Chris Chicoteau, Malcolm Connolly, Angela Cook, Tony Eales, Vanessa Krueger, Jill Reid, Lara Tilse, Deb Vale, Catherine Westcott and Paul Wise. Chris Clarkson drafted the original versions of Figures 1-2.

We also thank the managers of Fingerfield Macadamia Farm at Baffle Creek for their help with this study; Paul and Mia Francis of Cania Station, and Nerida, Peter and Matthew Jamieson and Karen
Gross for their support, hospitality and participation in this research. We are also very grateful to Des Mergard and family of 1770 Charter for their interest in our work and their invaluable assistance with transport in their LARC. Shire councillor Leo Miller proved keen on the strange rituals of archaeology, both in the pits and afterwards.

We are particularly grateful to Professor John Jell, who steered us through matters geological and microscopical, to Colin Campbell, who provided numerous references to facilitate our introduction to the world of foraminifera, and to Ian McNiven, who suggested that we look for forams in our middens. This volume would still not have appeared without the efforts of Jill Reid and Tony Eales (Aboriginal and Torres Strait Islander Studies Unit, University of Queensland) in checking data and commenting on several drafts.

On numerous occasions, Cathy, Hannah, Esther and Verity Lilley put up with extended absences, or with field conditions of variable quality to avoid such absences. They deserve thanks for their help as well as their forbearance.

\section{References Cited}

Alfredson, G. 1987 Report on the Archaeological Survey of and Collection from the Proposed Benaraby-Parana Realignment of the North Coast Railway. Unpublished report to McIntyre and Associates.

Alfredson, G. 1989 Report on an Initial Archaeological Survey of the Stuart Oil Shale Project. Unpublished report to Hollingsworth Consultants Pty Ltd, Brisbane.

Alfredson, G. 1990 Report on the Initial Archaeological Survey of the Proposed Monte Cristo Resort at Black Head Curtis Island. Unpublished report to Hollingsworth Consultants Pty Ltd, Brisbane.

Alfredson, G. 1991 Report on an Initial Archaeological Survey for the Gladstone Special Steel Project. Unpublished report to Hollingsworth Consultants Pty Ltd, Brisbane.

Alfredson, G. 1992 Gladstone Industrial Land Project Studies - Archaeology and Heritage - Stage. Unpublished report to Environmental Science Services, Brisbane.

Alfredson, G. 1993 Report on an Archaeological Inspection of a Proposed Residential and Recreational Development on Hummock Hill Island. Unpublished report to AGC Woodward-Clyde Pty Ltd.

Ball, L.C. 1915 Letter to Hamlyn-Harris, Queensland Museum 24 September 1915.

Barker, B.C. 1993 An Archaeological Survey of Eastern Boyne Island, Gladstone, Central Queensland. Unpublished report to Hollingsworth, Dames and Moore.

Beaton, J. 1977 Dangerous Harvest: Investigations in the Late Prehistoric Occupation of Upland South-East Central Queensland. Unpublished PhD thesis, Research 
School of Pacific and Asian Studies, Department of Prehistory, Australian National University, Canberra.

Burke, C. 1993 A Survey of Aboriginal Archaeological Sites on the Curtis Coast, Central Queensland. Unpublished report to the Queensland Department of Environment and Heritage, Rockhampton.

Carter, M. 1997 Chenier and Shell Midden: An Investigation of Cultural and Natural Shell Deposits at Rodds Peninsula, Central Queensland Coast. Unpublished B.A. (Hons) thesis, Department of Anthropology and Sociology, University of Queensland, Brisbane.

Carter, M., I. Lilley, S. Ulm and D. Brian this volume Mort Creek Site Complex, Curtis Coast: Site report. Queensland Archaeological Research 11.

Chapman, V. 1999 Drawing the Line: The Rock Painting of Cania Gorge, South Central Queensland. Unpublished PGDipArts (Anthropology), Department of Sociology, Anthropology and Archaeology, University of Queensland, Brisbane.

Chicoteau, C. 1998a An Analysis of Archaeological Charcoals from Square A, Grinding Groove Cave, Cania Gorge: A Feasibility Study of the Use of Archaeological Charcoals in Cania Gorge Rockshelter Deposits. Unpublished report submitted for ID232: Independent Project in Aboriginal and Torres Strait Islander Studies I, Aboriginal and Torres Strait Islander Studies Unit, University of Queensland.

Chicoteau, C. 1998b Two Hundred and Four Kilograms of What?: A Preliminary Site Report of Square A, Grinding Groove Cave, Cania Gorge, Focussing on Sedimentation Rates. Unpublished report submitted for ID233: Independent Project in Aboriginal and Torres Strait Islander Studies II, Aboriginal and Torres Strait Islander Studies Unit, University of Queensland.

Clarkson, C., M. Williams, I. Lilley and S. Ulm in prep. Gooreng Gooreng Contemporary Social Landscapes. Aboriginal and Torres Strait Islander Studies Unit Research Report Series. Brisbane: Aboriginal and Torres Strait Islander Studies Unit, University of Queensland.

Culbert, N. 1996 The Shell "Artefact" from A7. Unpublished report submitted for AY269: Independent Study I, Department of Anthropology and Sociology, University of Queensland.

David, B. and D. Chant 1995 Rock art and regionalisation in north Queensland prehistory. Memoirs of the Queensland Museum 37(2):357-528.

Davies, S. 1994 An Archaeological Assessment of the Proposed Queensland Rail Deviations on the Mainline Upgrade between Bundaberg and Gladstone, Queensland. UQASU Report 237. Brisbane: University of Queensland Archaeological Services Unit, Department of Anthropology and Sociology, University of Queensland.

Duncum, C. 1991 Archaeological Appraisal of the Southeastern Portion of the Proposed Coral Cove Development, near Bundaberg (Bundaberg KE),
Central Queensland, 6 December 1991. Unpublished report to Gutteridge Haskins and Davey.

Eales, T. 1998a Stone Soup: A Residue Analysis of Artefacts from Roof Fall Cave, Cania Gorge, Central Queensland. Unpublished B.A. (Hons) thesis, Department of Anthropology and Sociology, University of Queensland, Brisbane.

Eales, T. 1998b Determining Task by Residue Analysis of Stone Tools from Cania Gorge. Unpublished paper presented to the Australian Archaeological Association Annual Conference, Valla Beach Resort, December 1998.

Eales, T. in prep. The Archaeology of Cania Gorge (working title). Unpublished PhD thesis, Department of Sociology, Anthropology and Archaeology, University of Queensland, Brisbane.

Elkin, A.P. 1949 The origins and interpretation of petroglyphs in south-eastern Australia. Oceania 20:119-157.

Findlay, J.L. 1979 Results of Research Completed on Lithic Material from Bargara, near Bundaberg, SouthEast Queensland. Unpublished report submitted to the Department of Anthropology and Sociology, University of Queensland.

Frankland, K. 1990 Booral: A Preliminary Investigation of an Archaeological Site in the Great Sandy Region, Southeast Queensland. Unpublished B.A. (Hons) thesis, Department of Anthropology and Sociology, University of Queensland, Brisbane.

Godwin, L. 1990 Cultural heritage. In J. McCosker, Eurimbula National Park Draft Management Plan. Unpublished report to the Queensland Department of Environment and Heritage, Rockhampton.

Gorecki, P. 1995 The Burnett Shire Council Aboriginal Heritage Study: Stage 1. UQASU Report 268. Brisbane: University of Queensland Archaeological Services Unit, Department of Anthropology and Sociology, University of Queensland.

Hall, H.J. 1980 An Archaeological Assessment of the Alcan Smelter Site, Gladstone, Queensland. Unpublished report to James B. Croft and Associates, Sydney.

Hall, H.J. 1981 An Archaeological Assessment of the Lend Lease Corporation Coke Plant near Gladstone, Queensland. Unpublished report to Oceanics Australia Pty Ltd.

Hall, H.J. 1985 Initial Archaeological Survey of the Proposed Bucca Weir, Kolan River, S.E. Queensland. Unpublished report to Gutteridge, Haskins and Davey.

Hall, J. and P. Hiscock 1988 The Moreton Region Archaeological Project (MRAP) Stage II: An outline of objectives and methods. Queensland Archaeological Research 5:4-24.

Hamlyn-Harris, R. 1915 Notes on an exhibit of a small Aboriginal "camp" collection from near Bundaberg. Proceedings of the Royal Society of Queensland 27(2):103-104 
Hatte, E. 1992 Archaeological and Anthropological Investigations of the Proposed Route of the Fibre Optic Link: Bundaberg to Ban Ban Springs. Unpublished report to OVE ARUP and Partners.

Hill, I.W. 1978 An Archaeological Report on Boyne Island Sites and Road Corridors. Unpublished report to the Department of Environment and Heritage, Brisbane.

Hiscock, P. 1982 An Archaeological Assessment of Site 1, Awoonga Dam, Queensland. Unpublished report to the Gladstone Area Water Board.

Hiscock, P.D. 1988 Prehistoric Settlement Patterns and Artefact Manufacture at Lawn Hill, Northwest Queensland. Unpublished PhD thesis, Department of Anthropology and Sociology, University of Queensland, Brisbane.

Holdaway, S. 1995 Stone artefacts and the transition. Antiquity 69:784-797.

Horsfall, N. 1979 An Analysis of some Stone Artifacts Collected near Bundaberg. Unpublished report submitted to the Department of Anthropology and Socielogy, University of Queensland.

Horsfall, N. and J. Findlay 1979 Eloueras from Southeast Queensland: Museum Collections as an Archaeological Resource. Unpublished report to the Queensland Museum.

Horton, D. (ed.) 1994 The Encyclopaedia of Aboriginal Australia: Aboriginal and Torres Strait Islander History, Society and Culture. Canberra: Aboriginal Studies Press.

Hughes, P.J. and R.J. Lampert 1977 Occupational disturbance and types of archaeological deposit. Journal of Archaeological Science 4:35-40.

Johnson, I. 1979 The Getting of Data: A Case Study from the Recent Industries of Australia. Unpublished PhD thesis, Research School of Pacific and Asian Studies, Department of Prehistory, Australian National University, Canberra.

Jolly, L. 1994 Gureng Gureng: A Language Program Feasibility Study. Aboriginal and Torres Strait Islander Studies Unit Research Report Series 1. Brisbane: Aboriginal and Torres Strait Islander Studies Unit, University of Queensland.

L'Estrange, S. 1998 Tainted Glass. Unpublished report submitted for ID233: Independent Project in Aboriginal and Torres Strait Islander Studies II, Aboriginal and Torres Strait Islander Studies Unit, University of Queensland.

Lauer, P.K. 1977 Report of a preliminary ethnohistorical and archaeological survey of Fraser Island. In P.K. Lauer (ed.), Occasional Papers in Anthropology 8:138. St Lucia: Anthropology Museum, University of Queensland.

Lauer, P.K. 1979 The museum's role in fieldwork: The Fraser Island study. In P.K. Lauer (ed.), Occasional Papers in Anthropology 9:31-72. St Lucia: Anthropology Museum, University of Queensland.

Lilley, I. 1980 Report on the Archaeological Impact of the
Proposed Development of the Awoonga Dam, Boyne River, Central Queensland. Unpublished report to Peter Hollingsworth and Associated Consultants.

Lilley, I. 1994a An Archaeological Assessment of Proposed Sand-Mining on Middle Island, Coastal Central Queensland. UQASU Report 244. Brisbane: University of Queensland Archaeological Services Unit, Department of Anthropology and Sociology, University of Queensland.

Lilley, I. 1994b A Summary Assessment of Aboriginal Cultural Heritage Values in the Proposed Walla Weir and Wallaville Bridge Impact Areas, Bundaberg, Southeast Queensland. Unpublished report to Kinhill Cameron McNamara Pty Ltd.

Lilley, I. 1994c The Gooreng Gooreng Cultural Heritage Project: An Initial Statement. Unpublished paper presented to the Australian Archaeological Association Annual Conference, La Trobe University, Bundoora, December 1994.

Lilley, I. 1995a An Archaeological Assessment of the Cultural Heritage Values of the Swindon Gold Prospect at Mt Rawdon, via $\bar{M} t$ Perry, Central Queensland. Unpublished report to Placer Pacific Ltd.

Lilley, I. 1995b An Archaeological Assessment of the Aboriginal Archaeological Impact of the Proposed Gold Mine at Mt Rawdon, Central Queensland. Unpublished report to Placer Pacific Ltd.

Lilley, I. 1995c An Archaeological Assessment of the Aboriginal Cultural Heritage Values of the Proposed Mini Excavations Sand Extraction Project, Yarwun, Coastal Central Queensland. Unpublished report to Kinhill Cameron McNamara Pty Ltd.

Lilley, I. 1995d An Archaeological Assessment of the Cultural Heritage Values of the Proposed Perry River Dam, Mt Rawdon, Central Queensland. Unpublished report to Placer Pacific Pty Ltd.

Lilley, I. 1995e An Archaeological Assessment of the Cultural Heritage Values of the Proposed Agnes Water Sewage Treatment Plant and Irrigation Area, Agnes Water, Coastal Central Queensland. Unpublished report to Kinhill Cameron McNamara Pty Ltd.

Lilley, I. 1995f The Goreng Goreng Cultural Heritage Project. Unpublished paper presented to the Department of Anthropology and Sociology, University of Queensland, 19 May 1995.

Lilley, I. 1997 The Gooreng Gooreng Archaeological Project, Central Queensland, Australia. Waikato Radiocarbon Laboratory Newsletter 4:3.

Lilley, I. and D. Brian 1995 I think...there! Foram(inifera). Unpublished paper presented to the 1995 Taphonomy Symposium, Australian National University, Canberra, April 1995.

Lilley, I., D. Brian, C. Clarkson and S. Ulm 1998 Pleistocene Aboriginal occupation at Cania Gorge, Central Queensland: Preliminary results of fieldwork. Archaeology in Oceania 33(1):28-31.

Lilley, I., D. Brian and S. Ulm 1999 The use of 
foraminifera in the identification and analysis of marine shell middens: A view from Australia. In M-J. Mountain and D. Bowdery (eds), Taphonomy: The Analysis of Processes from Phytoliths to Megafauna, pp.9-16. Research Papers in Archaeology and Natural History 30. Canberra: Archaeology and Natural History Publications, Research School of Pacific and Asian Studies, Australian National University.

Lilley, I. and S. UIm 1995 The Gooreng Gooreng Cultural Heritage Project: Some proposed directions and preliminary results of the archaeological program. Australian Archaeology 41:11-15.

Lilley, I., S. Ulm and D. Brian 1996 The Gooreng Gooreng Cultural Heritage Project: First radiocarbon determinations. Australian Archaeology 43:38-40.

Lilley, I. and M. Williams with Members of the Gurang Land Council Aboriginal Corporation 1997 The Gooreng Gooreng Contemporary Social Landscape Project. Unpublished paper presented to the 'Meanings of Archaeology' seminar series hosted by the Australian Institute of Aboriginal and Torres Strait Islander Studies, Canberra, September 1997.

Lilley, I., M. Williams and S. Ulm 1997 The Gooreng Gooreng Cultural Heritage Project: A Report on National Estate Grants Program Research, 1995-1996. 2 vols. Brisbane: Aboriginal and Torres Strait Islander Studies Unit, University of Queensland.

Lilley, I., M. Williams, S. Ulm, D. Brian, C. Clarkson, M. Carter, J. Reid and C. Westcott 1997a Gooreng Gooreng Cultural Heritage Project Four Years On. Unpublished paper presented to the Aboriginal and Torres Strait Islander Studies Unit, University of Queensland, June 1997

Lilley, I., M. Williams, S. Ulm and D. Brian 1997b Gooreng Gooreng Cultural Heritage Project: Results of June-July Fieldwork. Unpublished paper presented to the Aboriginal and Torres Strait Islander Studies Unit, University of Queensland, August 1997.

Lourandos, H. 1997 Continent of Hunter-Gatherers: New Perspectives in Australian Prehistory. Cambridge: Cambridge University Press.

McAllister, P. 1995 Artefacts date to 5000 years: Major indigenous archaeological find. Gladstone Observer 19 April:4.

McNiven, I. 1990 Prehistoric Aboriginal Settlement and Subsistence in the Cooloola Region, Coastal Southeast Queensland. Unpublished PhD thesis, Department of Anthropology and Sociology, University of Queensland, Brisbane.

McNiven, I.J. 1998 Aboriginal archaeology of the Corroboree Beach dune field, Fraser Island: Re-survey and re-assessment. Memoirs of the Queensland Museum, Cultural Heritage Series 1(1):1-22.

Mathews, R.H. 1897 Rock carvings and paintings of the Australian Aborigines. Proceedings of the American Philosophical Society 36:466-487.

Mathews, R.H. 1910 Some rock pictures and ceremonial stones of the Australian Aborigines. Report of the
Twelfth Meeting of the Australasian Association for the Advancement of Science Held in Brisbane, 1909 12:493-498.

Maynard, L. 1976 An Archaeological Approach to the Study of Australian Rock Art. Unpublished M.A. thesis, University of Sydney, Sydney.

Maynard, L. 1979 The archaeology of Australian Aboriginal art. In S.M. Mead (ed.), Exploring the Visual Art of Oceania: Australia, Melanesia, Micronesia and Polynesia, pp.83-110. Honolulu: University of Hawaii Press.

Morwood, M. 1979 Art and Stone: Towards a Prehistory of Central Western Queensland. Unpublished PhD thesis, Department of Archaeology and Anthropology, Faculty of Arts, Australian National University, Canberra.

Morwood, M. 1981 Archaeology in the Central Queensland Highlands: The stone component. Archaeology in Oceania 16(1):1-52.

Morwood, M. 1984 The prehistory of the Central Queensland Highlands. Advances in World Archaeology 3:325-379.

Morwood, M.J. and D.R. Hobbs 1995 Themes in the prehistory of tropical Australia. Antiquity 69:747-768.

Mulvaney, J. and E. Joyce 1965 Archaeological and geomorphological investigations on Mt. Moffat Station, Queensland, Australia. Proceedings of the Prehistoric Society 31:147-212.

Neal, R.A. 1986 Results of the Archaeological Inspection of Proposed Telecom DRCS and Broadband Locations for December 1986. Unpublished report to Telecom Australia.

Nicholson, A. and S. Cane 1994 Pre-European coastal settlement and use of the sea. Australian Archaeology 39:108-117.

QDEH 1994 Curtis Coast Study: Resource Report. Rockhampton: Queensland Department of Environment and Heritage.

Quinnell, M.C. 1976 Aboriginal Rock Art in Carnarvon Gorge, South Central Queensland. Unpublished M.A. thesis, University of New England, Armidale.

Reid, J. 1997 Results and Analysis of E1: An Investigation of the Archaeological Record of the Eurimbula Shell Midden Complex, Central Queensland Coast. Unpublished report submitted for ID232: Independent Project in Aboriginal and Torres Strait Islander Studies I, Aboriginal and Torres Strait Islander Studies Unit, University of Queensland.

Reid, J. 1998 An Archaeological Approach to Quarry Studies: A Technological Investigation of the Ironbark Site Complex, Southern Curtis Coast, Australia. Unpublished B.A. (Hons) thesis, Department of Anthropology and Sociology, University of Queensland, Brisbane.

Richardson, N. 1992 Conjoin sets and stratigraphic integrity in a sandstone shelter: Kenniff Cave (Queensland, Australia). Antiquity 66:408-418. 
Ringland, P. 1978 Survey of Facing Island. Unpublished report to the Department of Environment and Heritage, Brisbane.

Rola-Wojciechowski, C. 1983 'A Bit of Bundy': The 'Bundaberg' Engraving Site. Unpublished B.A. (Hons) thesis, Department of Prehistory and Archaeology, University of New England, Armidale.

Rowland, M.J. 1981 Radiocarbon dates for a shell fishhook and disc from Mazie Bay, North Keppel Island. Australian Archaeology 15:63-69.

Rowland, M.J. 1985 Further radiocarbon dates from Mazie Bay, North Keppel Island. Australian Archaeology 21:113-118.

Rowland, M.J. 1987 Preliminary Archaeological Survey of Coastal Areas of the Bundaberg 1:250,000 Sheet (KE). Unpublished report to the Queensland Department of Environment and Heritage, Brisbane.

Rowland, M.J. 1992 Conservation Plan for Cultural Heritage Sites on the Keppel Island Group, Central Queensland. Unpublished report to the Livingstone Shire Council and National Parks and Wildlife Branch. Division of Conservation, Department of Environment and Heritage, Brisbane.

Suarez, Y. 1998 The Burnett River Engravings Site. Unpublished report submitted for ID233: Independent Project in Aboriginal and Torres Strait Islander Studies II, Aboriginal and Torres Strait Islander Studies Unit, University of Queensland.

Schultz, J. 1997 Looking for clues. The Courier Mail 29 December:7.

Smith, M.A. 1989 Seed gathering in inland Australia: Current evidence from seed-grinders on the antiquity of the ethnohistorical pattern of exploitation. In D.R. Harris and G.C. Hillman (eds), Foraging and Farming: The Evolution of Plant Exploitations, pp.305-317. London: Unwin Hyman.

Spencer, T. 1995 A Cultural Heritage Survey of Three Mining Lease Application Areas-Upper Burnett River Near Monto Southern Queensland. Unpublished report to Lewis Environmental Consultants for Monto Resources Pty Ltd.

Stanton, J.P. and M.G. Morgan 1977 The rapid selection and appraisal of key and endangered sites: The Queensland case study. School of Natural Resources Report P.R.4. Armidale: School of Natural Resources, University of New England.

Stern, N. 1980 Taphonomy: Some Observations about its Place in Archaeology. Unpublished B.A. (Hons) thesis, Department of Prehistoric and Historical Archaeology, University of Sydney, Sydney.

Sutcliffe, K.A. 1972 Removal of Rock Engravings from the Burnett River, Queensland. Unsubmitted draft M.A. thesis, Department of Anthropology and Sociology, University of Queensland, Brisbane.

Sutcliffe, K.A. 1974 Removal of Aboriginal rock engravings: Burnett River. Anthropological Society of Queensland Newsletter 65.
Tindale, N.N. 1974 Aboriginal Tribes of Australia. Berkeley: University of California Press.

Ulm, S. 1997 Late Holocene Coastal Mobility Strategies: Research in the Southern Curtis Coast Region. Unpublished paper presented to the Department of Anthropology and Sociology, University of Queensland, 24 October 1997.

Ulm, S. in prep. Late Holocene Aboriginal Mobility Strategies and Localisation on the Southern Curtis Coast, Central Queensland, Australia. Unpublished PhD thesis, Department of Sociology, Anthropology and Archaeology, University of Queensland, Brisbane.

Ulm, S., B. Barker, A. Border, J. Hall, I. Lilley, I. McNiven, R. Neal and M. Rowland 1995 Pre-European coastal settlement and use of the sea: A view from Queensland. Australian Archaeology 41:24-26.

Ulm, S. and J. Hall 1996 Radiocarbon and cultural chronologies in southeast Queensland prehistory. In S. Ulm, I. Lilley and A. Ross (eds), Australian Archaeology "95: Proceedings of the 1995 Australian Archaeological Association Annual Conference, pp.4562. Tempus 6. St Lucia: Anthropōology Museum, University of Queensland.

Ulm, S. and I. Lilley 1996 The Gooreng Gooreng Cultural Heritage Project and repatriation of the Burnett River engravings. WAC (World Archaeological Congress) News (Indigenous Focus) 4(1):iii-iv.

Ulm, S., M. Carter, J. Reid and I. Lilley this volume Eurimbula Site 1, Curtis Coast: Site report. Queensland Archaeological Research 11.

Ulm, S. and I. Lilley this volume The archaeology of the southern Curtis Coast: An overview. Queensland Archaeological Research 11.

Ulm, S., I. Lilley and M. Williams 1997 'Bringing Them Back Home': Repatriating the Burnett River Engravings. Unpublished paper presented to the Aboriginal and Torres Strait Islander Studies Unit, University of Queensland, 10 October 1997.

Veth, P. 1989 Islands in the interior: A model for the colonisation of Australia's arid zone. Archaeology in Oceania 24(3):81-92.

Walsh, G.L. 1984 Managing the Archaeological Sites of the Sandstone Belt. Rockhampton: Central Queensland Aboriginal Corporation for Cultural Activities and the Queensland National Parks and Wildlife Service.

Westcott, C. 1997 A Technological Analysis of the Stone Assemblage from Big Foot Art Site, Cania Gorge. Unpublished B.A. (Hons) thesis, Department of Anthropology and Sociology, University of Queensland, Brisbane.

Westcott, C., I. Lilley and S. Ulm this volume The archaeology of Cania Gorge: An overview. Queensland Archaeological Research 11.

Williams, M. 1981 Traditionally, My Country and its People. Unpublished MPhil (Qual.) thesis, Griffith University, Brisbane. 